\title{
Development Electronic Student Worksheet based on Relating, Experiencing, Applying, Cooperating, and Transferring (REACT) in Introduction to Chemistry and Laboratory
}

\author{
Yusup Maulana1,2*, Imas Eva Wijayanti ${ }^{2}$ and Solfarina ${ }^{2}$ \\ ${ }^{1}$ Department of Elementary Education, Graduate School of Universitas Pendidikan \\ Indonesia, Jalan Dr. Setiabudhi 229 Bandung 40154, Indonesia \\ 2 Department of Chemistry Education, Faculty of Teacher Training and Education, \\ Universitas Sultan Ageng Tirtayasa, Jalan Ciwaru Raya, Serang City, Banten 42117, \\ Indonesia \\ *E-mail:yusupmaulana@upi.edu
}

Received: 18 November 2021; Accepted: 19 December 2021; Published: 31 December 2021

\begin{abstract}
This research aims to development a REACT-based e-worksheet that is feasible to use to stimulate the critical thinking, creativity, collaboration, communication (4C) skills and determine student response. The challenges of a dynamic era require students to have a $4 \mathrm{C}$ skills set critical thinking and problem-solving skills; creativity and innovation; communication; and collaboration. One of the tools that can be used in online learning to achieve this goal is to use the electronic Student Worksheet (E-Worksheet) which includes the student's $4 \mathrm{C}$ skill values with REACT strategies: Relating, Experiencing, Applying, Cooperating, and Transferring. The research chooses one of the topics in chemistry, which is introduction to chemistry and laboratories. This REACT-based e-worksheet was developed using the ADDIE development model which consists of five stages those are analysis, design, development, implementation, and evaluation. In addition, the study used a sample of 10 students of mathematic and natural science $12^{\text {th }}$ grade MAN 4 Tangerang. Based on the results of validation and student response questionnaires, REACT-based e-worksheet to stimulate students' $4 C$ skills was declared valid and obtained an average percentage of $91.8 \%$ with very good criteria.
\end{abstract}

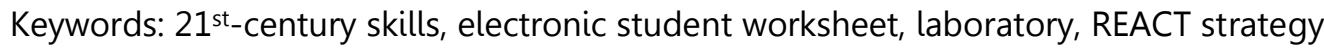

DOI: https://doi.org/10.15575/jtk.v6i2.14988

\section{Introduction}

Preparation of human resources through education is an important things because it includes the implementation of the 2013 curriculum which has accommodated Critical thinking, Communication, Collaboration, and Creativity skills (4C), both from content standards, process standards, and assessment standards (Redhana, 2019). In the standard process, educators are expected to apply scientific learning. But most of the current phenomena, learning is still teacher-centered, resulting in students not mastering the $4 \mathrm{C}$ skills optimally. Therefore, the answer to this problem is a learning reform that shifts educator-centered learning to studentcentered learning (Abidin, 2016).

The existence of learning reforms that are in line with the industrial revolution 4.0 can produce very fast changes (Rezky et al., 2019). The knowledge aspect, knowledge-based economy, and information technology are no exception. This change needs to be responded to with readiness to master various skills. In the field of education, the skills that must be mastered are Critical thinking, Communication, Collaboration, and Creativity skills (4C) (Slamet Widodo, 2020). 4C skills can be developed in all disciplines, including 
Development Electronic Student Worksheet based on Relating, Experiencing, Applying, Cooperating, and Transferring (REACT) in Introduction to Chemistry and Laboratory

Chemistry as one of the Natural Science disciplines which is the basis of many other disciplines.

Chemistry is the study of composition, structure, properties, changes, and the accompanying energy which is sometimes complex and abstract (Redhana, 2019). Chemistry also studies concepts, theories, and laws through various natural phenomena that occur by linking three levels, which are macroscopic, microscopic, and symbolic. (Zidny et al., 2015). With these characters, it is not uncommon for students to experience difficulties, causing motivation in learning chemistry to be quite low. With limited time, students must understand these concepts so that they will also affect student learning outcomes. This causes the learning methods and tools used by the teacher to be adjusted so that the learning process goes according to plan (Rahmawati \& Yonata, 2019).

The learning process according to the plan requires the preparation of learning tools (RPP) and teaching materials (worksheet) (Nasrah et al., 2017). The use of teaching materials such as worksheet has not been maximized. Based on the results of observations that (Rahmawati \& Yonata, 2019) in ten high schools in East Jakarta, the use of worksheet is generally not maximized. This worksheet only contains a summary of the material, practice questions, and rarely relates the material to phenomena in everyday life. This causes the teaching and learning process to be ineffective and not according to plan. The use of worksheet that can maximize student skills can be based on learning models or learning strategies, so that the stages in the worksheet can be arranged and can be linked to everyday life, so REACT is the answer in the preparation of this worksheet.

The preparation of the worksheet can be based on a model or learning strategy by the objectives of the preparation of the worksheet (Makhrus et al., 2018). In this development research, worksheet is prepared based on the REACT strategy. REACT is one of the strategies used in the Context-Based Approach, and consists of five stages: Relating, Experiencing,
Applying, Cooperating, and Transferring (Gu"nter, 2018) in the steps of learning chemistry material is associated with life or phenomena that occur in nature. Table 1 shows the steps in the REACT strategy (Sugandi \& Akbar, 2019).

Table 1. REACT Strategy Phases and Activities

\begin{tabular}{cl}
\hline \multicolumn{1}{c}{ Phases } & \multicolumn{1}{c}{ Activity } \\
\hline Relating & $\begin{array}{l}\text { Students are guided by the } \\
\text { teacher to connect the concept } \\
\text { of the material in learning with } \\
\text { the knowledge possessed by } \\
\text { students }\end{array}$ \\
\hline Experiencing & $\begin{array}{l}\text { Students conduct research } \\
\text { (explore, search, and discover } \\
\text { new concepts to be studied) and } \\
\text { the teacher provides } \\
\text { explanations to direct students } \\
\text { to find new knowledge }\end{array}$ \\
\hline Applying & $\begin{array}{l}\text { Students apply the knowledge } \\
\text { learned in everyday life }\end{array}$ \\
\hline Cooperating & $\begin{array}{l}\text { Students conduct group } \\
\text { discussions to solve problems } \\
\text { and develop the ability to } \\
\text { collaborate with friends }\end{array}$ \\
\hline Transfering & $\begin{array}{l}\text { Students demonstrate the ability } \\
\text { to learn the knowledge and } \\
\text { apply it in new situations or } \\
\text { contexts }\end{array}$ \\
\hline
\end{tabular}

This REACT strategy is expected to be able to accelerate the process of understanding students because it stimulates 4C skills (Nur et al., 2019). The choice of this strategy can be applied to the topic of knowing chemistry and laboratories because this topic has just been included in the 2013 curriculum as a basic competency, so it is vulnerable to being ignored by teachers before teaching chemistry because they are pursuing learning targets for other topics. (Subagia, 2014). Even though knowing chemistry and laboratories are very important to be conveyed to students so that they can prepare themselves before studying chemistry, especially before conducting experiments in the laboratory to maintain work safety in the laboratory. This topic is taught in $10^{\text {th }}$ grade odd semesters, focusing on basic competencies 3.1, which are understanding the nature of chemistry, scientific methods and work safety in laboratories and the role of chemistry in life,

This is an open access article under CC-BY-SA license (https://creativecommons.org/licenses/by-sa/4.0/) 
Development Electronic Student Worksheet based on Relating, Experiencing, Applying, Cooperating, and Transferring (REACT) in Introduction to Chemistry and Laboratory

and basic competencies 4.1 which is presenting observations about the nature of chemistry, scientific methods, and safety in studying chemistry and the role of chemistry in life. This basic competence allows students to relate phenomena that occur in learning so that the learning process becomes more meaningful (Winaryati, 2018).

The phenomenon of the Covid-19 pandemic which causes a lot of learning to be done online (Dewi \& Sadjiarto, 2021; Herdiana, 2020; Herliandry et al., 2020; Jamaluddin et al., 2020; Khasanah et al., 2020), the use of eworksheet in PDF form as well as linking to many networks, allows students to learn audio-visually. So that this is expected to meet the needs of students to hone $4 C$ skills that can be used and read anywhere. Therefore, researchers are interested in conducting research entitled "Development of eworksheet based on Relating, Experiencing, Applying, Cooperating, and Transferring (REACT) as a Stimulator of Students' 4C Skills in Recognizing Chemistry".

\section{Research Method}

The method used is Research and Development $(R \& D)$ by developing a product to test the feasibility of the product. The research and development model used is the ADDIE model (Analyze, Design, Develop, Implement, and Evaluate) (Corbeil et al., 2005). This e-worksheet was developed through an analysis phase which includes literature review analysis, needs analysis, and material analysis. The design stage is carried out by designing or making e-worksheet, the content analysis stage and task list are carried out by analyzing core competencies and basic competencies. In the Development phase, the REACT-based eworksheet was developed on the topic of knowledge of chemistry and laboratories and at this stage validation of material and media, experts were also carried out. The Implement stage is carried out with limited trials to students. The next stage is the Evaluate stage, the evaluation process is carried out by analyzing improvements to errors and deficiencies during the research process.
The chemical materials implemented in the development of this e-worksheet are Knowledge of Chemistry and Laboratories. Validation was tested by eight validators which are media expert lecturers and material or content experts, and tested by chemistry teachers from several high schools in Serang and Tangerang, then students responded to the e-worksheet that had been used by filling out a questionnaire. The e-worksheet was limited to ten students of class $12^{\text {th }}$ grade mathematics and natural science MAN 4 Tangerang, because during $10^{\text {th }}$ grade they had not received material about chemistry and laboratories, besides that the class was the most likely to be tested during a pandemic.

Data collection in this study used a technique that was adapted to the ADDIE stages which are 1) Needs Analysis at the Analyze stage is through a literature study. What is done in the literature study is to examine the results of similar studies conducted by previous researchers. 2) Validation Sheet to assess eworksheet at the Develop stage, e-worksheet validation sheet consisting of five aspects, which are aspects of content feasibility, presentation, linguistic, contextual, and graphic. 3) Student Response Questionnaire Sheet for e-worksheet at the Implement stage. 4) Questionnaire sheets are distributed to students who have finished using REACTbased e-worksheet. It aims to determine the responses of students and teachers to the developed learning media.

The data analysis technique in this study is the data obtained through the results of student questionnaires and content and media expert validation sheets, data processing is carried out using qualitative descriptive analysis and quantitative analysis. Validation sheet data were analyzed using the validity index of Aiken (1985). The validity assessment scale in the content validation instrument uses a scale of 4 $(1,2,3,4)$, the alternative form of choice for the statement used in this study is "good", then the rating scale is determined to be Very Good, Good, Fairly Good and Less Good. Processing of data on the validation sheet by giving a tick $(\sqrt{ })$ in the alternative answer 
Development Electronic Student Worksheet based on Relating, Experiencing, Applying, Cooperating, and Transferring (REACT) in Introduction to Chemistry and Laboratory

column with a positive statement on a scale of four.

The data that has been obtained is tabulated and the validity value is calculated and then analyzed. The validity of the components on the validation sheet is calculated and processed using the content validity test from Aiken (1985), determining the validity of the statement items in the content validation instrument by comparing them with the minimum validity values in the Aiken $\mathrm{V}$ index table. (Aiken, 1985). The value of the validity of the items in this validation instrument is calculated by the Eq. (1):

$$
V=\frac{\sum S}{[n(c-1)]}(1)
$$

$\mathrm{V}=$ Content validity

$10=$ minimum score

$S=$ reduced scorer $(r)$ with a minimum score (10)

$\mathrm{n}=$ number of raters,

$\mathrm{c}=$ maximum score

In this study, eight validators were involved to assess the e-worksheet developed with an answer scale of four, and an error rate of 0.05 , so the minimum validity value must be obtained so that the items in the instrument are valid is 0.75 . If the value of $V_{\text {count }}>V_{\text {table }}$ then the item is declared valid $\left(V_{\text {table }}=0.75\right)$ (Aiken, 1985)

Student response questionnaire data uses a Likert scale, student response questionnaires are distributed using a google form, students choose one statement in the answer that there are five answer choices. The alternative answer choices used in this study were Strongly Agree, Agree, Less Disagree, Disagree and Strongly Disagree. The percentage of student responses to the developed e-worksheet is calculated using the following Eq. (2) (Sugiyono, 2018):

$$
p=\frac{\mathrm{f}}{\mathrm{n}} \times 100 \%(2)
$$

$p=$ percentage of answers

$f=$ frequency of each answer to the questionnaire

$\mathrm{n}=$ number of ideal scores

\section{Result and Discussion}

\subsection{Analyze Stage}

The analysis carried out in this study went through a series of stages to obtain the data needed in a series of development processes. This e-worksheet was developed through an analysis phase which includes literature review analysis, needs analysis, and material analysis. The literature review analysis was carried out by analyzing several journals related to the problems that occur in learning on chemistry, in addition to analyzing the Core Competencies, Basic Competency analysis, learning indicators adapted to Basic Competencies, as well as the contents of elearning. worksheet is adjusted to the latest high school curriculum.

\subsection{Design Stage}

In this design stage, the design or manufacture of e-worksheet is carried out at the content analysis stage and task list which are by analyzing core competencies and basic competencies. The initial stage in the preparation of the task produces learning indicators or indicators of competency achievement on the topic of knowing chemistry. Table 2 shows the Basic Competencies and Table 3 shows the indicators derived from the basic competencies on the topic of knowing chemistry and laboratories in the 2013 Revised Curriculum in Permendikbud RI No. 37 of 2018, then these indicators become the basis for compiling content in e-worksheet.

\begin{tabular}{c} 
Table 2. Basic Competencies of Knowing \\
Chemistry and Laboratories \\
\hline \multicolumn{1}{c}{ Basic Competencies } \\
\hline $3.1 \quad \begin{array}{l}\text { Explain the scientific method, the } \\
\text { nature of chemistry, safety and security } \\
\text { in the laboratory, and the role of } \\
\text { chemistry in everyday life } \\
\text { Presenting the results of the design } \\
\text { and the results of scientific } \\
\text { experiments }\end{array}$ \\
\hline
\end{tabular}


Development Electronic Student Worksheet based on Relating, Experiencing, Applying, Cooperating, and Transferring (REACT) in Introduction to Chemistry and Laboratory

Table 3. Indicators of Learning to Know Chemistry and Laboratories Learning Indicators

\begin{tabular}{|c|c|}
\hline \multicolumn{2}{|r|}{ Learning Indicators } \\
\hline 3.1 .1 & Explain the scientific method \\
\hline 3.1 .2 & Explain the nature of chemistry \\
\hline 3.1 .3 & $\begin{array}{l}\text { Explain the role of chemistry in } \\
\text { everyday life }\end{array}$ \\
\hline 3.1 .4 & $\begin{array}{l}\text { Linking laboratory rules with work } \\
\text { safety }\end{array}$ \\
\hline 4.1.1 & $\begin{array}{l}\text { Sorting chemical products based on } \\
\text { their function in life }\end{array}$ \\
\hline 4.1.2 & $\begin{array}{l}\text { Designing a simple } \\
\text { experiment }\end{array}$ \\
\hline 4.1.3 & $\begin{array}{l}\text { Presenting the results of a simple } \\
\text { scientific experiment }\end{array}$ \\
\hline
\end{tabular}

\subsection{Development Stage}

This stage is the development of REACT-based e-worksheet on the topic of knowledge of chemistry and laboratories in the form of making formative evaluation sheets, and eworksheet summative evaluation sheets with the help of content validation methods from material and media experts. e-worksheet that has been validated by experts, the validity of the resulting data is calculated using the validity formula of Aiken (1985) so that eworksheet is considered valid and suitable for use in learning. Table 4 shows the results of eworksheet validation from experts on the feasibility of content.

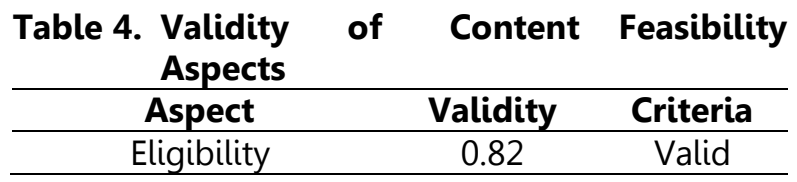

In the aspect of the feasibility of the content of the indicators assessed, which are the suitability of the material with basic competicies, the accuracy of the material, the updating of the material, and encouraging curiosity. The content feasibility aspect gets 0.82 validity with valid criteria. Table 5 shows the results of e-worksheet validation from experts on the presentation aspect.

Table 5. Validity of the Presentation Aspect

\begin{tabular}{ccc}
\hline Aspect & Validity & Criteria \\
\hline Presentation & 0,79 & Valid \\
\hline
\end{tabular}

In the aspect of the presentation, the indicators assessed are presentation techniques, presentation support, presentation of coherence learning, and the coherence of the flow of thought. The presentation aspect gets 0.79 validity with valid criteria. Table 6 shows the results of eworksheet validation from experts on the linguistic aspect.

Table 6. Validity of Linguistic Aspects

\begin{tabular}{ccc}
\hline Aspect & Validity & Criteria \\
\hline Linguistic & 0.82 & Valid \\
\hline
\end{tabular}

In the linguistic aspect, the indicators assessed are straightforward, communicative, dialogical and interactive, conformity to the development of students, conformity to language rules. The content feasibility aspect gets 0.82 validity with valid criteria. Table 7 shows the results of e-worksheet validation from experts on contextual aspects (REACT).

Table 7. Validity of Contextual Aspects (REACT)

\begin{tabular}{ccc}
\hline Aspect & Validity & Criteria \\
\hline $\begin{array}{c}\text { Contextual } \\
\text { (REACT) }\end{array}$ & 0.8 & Valid \\
\hline
\end{tabular}

In the aspect of feasibility, the content of the indicators assessed is the contextual nature, the contextual component, and the REACT component. This feasibility aspect gets a validity of 0.8 with valid criteria. Furthermore, table 8 shows the results of e-worksheet validation from experts in the graphic aspect.

Table 8. Validity of Each Graphical Aspect

\begin{tabular}{ccc}
\hline Aspect & Validity & Criteria \\
\hline Graphical & 0.83 & Valid \\
\hline
\end{tabular}

In the graphic aspect, the indicators assessed are size, cover design, and content design. The graphic aspect has a validity of 0.83 with valid criteria. Based on the results of expert validation, a REACT-based e-worksheet was produced which could then be implemented for students. Figure 1 shows an overview of the revised e-worksheet on topic 1 (Knowing Chemistry) and Figure 2 shows an overview of the revised results on topic 2 (Knowing Laboratories). 
Development Electronic Student Worksheet based on Relating, Experiencing, Applying, Cooperating, and Transferring (REACT) in Introduction to Chemistry and Laboratory

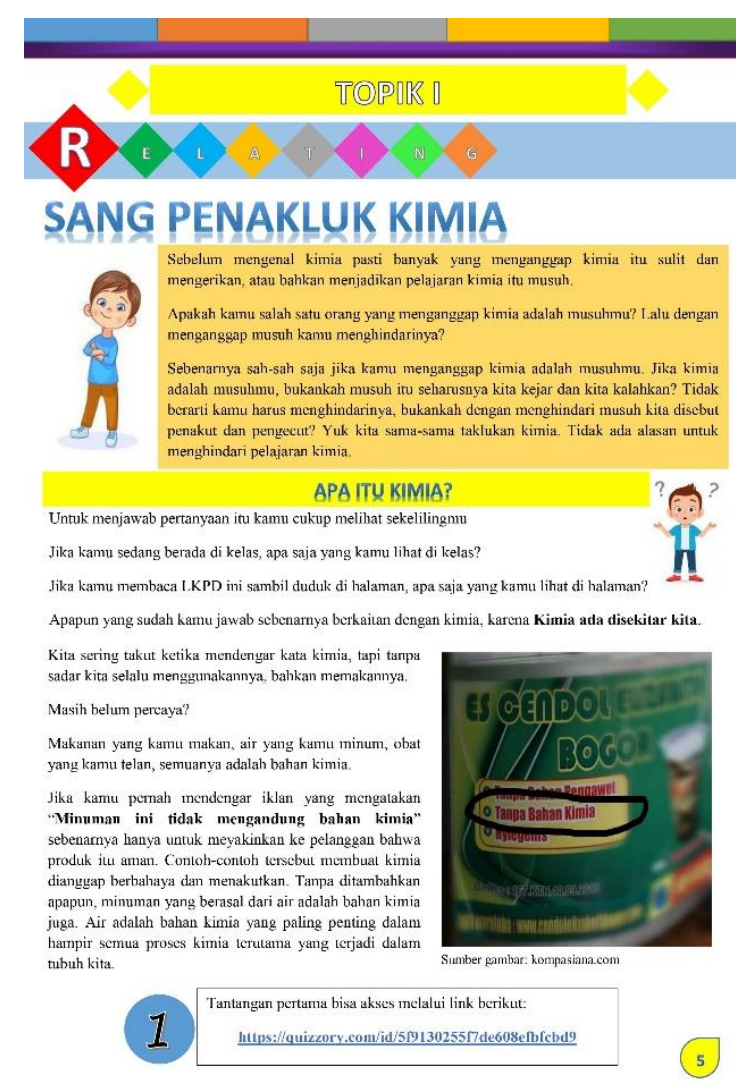

Figure 1. Results of Topic 1 Revision (Knowing Chemistry)

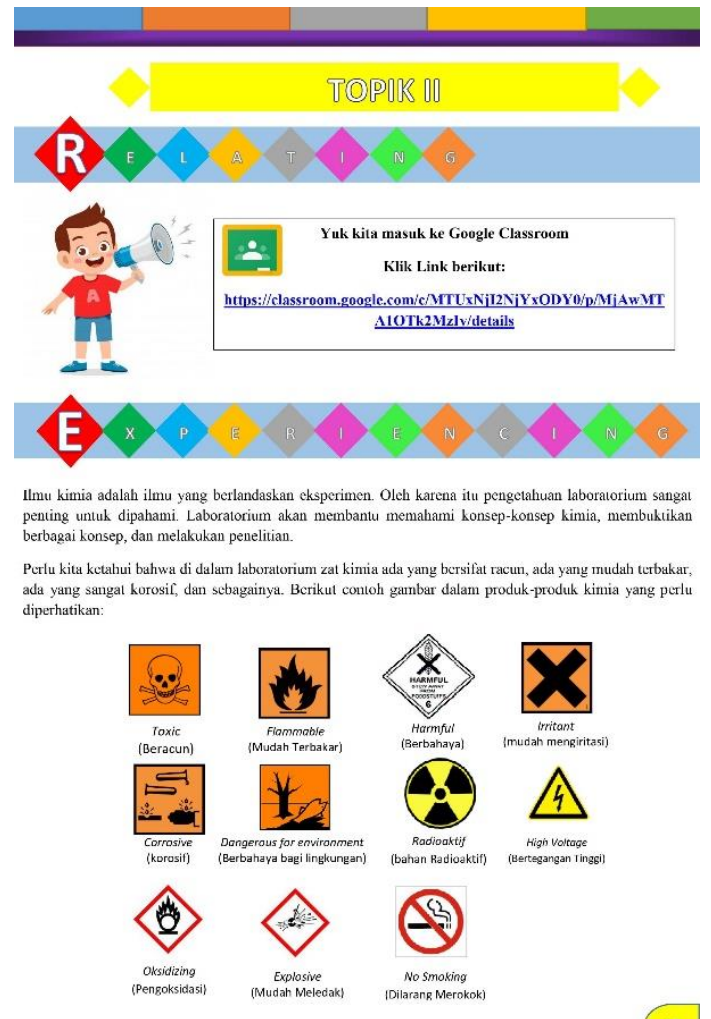

Figure 2. Results of Topic 2 Revision (Knowing The Laboratory)

\subsection{Implementation Stage}

At this stage, the e-worksheet is ready to be tested on 10 students who have studied the material about chemistry. The data obtained from the distribution of the questionnaire was then processed in the form of a percentage which was then interpreted based on the assessment criteria. Table 9 shows the final results of processing student response questionnaire data.

Table 9. Student Response Questionnaire Data

\begin{tabular}{ccc}
\hline Rated Aspect & $\begin{array}{c}\text { Presentation } \\
\text { (\%) }\end{array}$ & Criteria \\
\hline $\begin{array}{c}\text { e-worksheeet } \\
\text { attraction }\end{array}$ & 89.4 & Very Good \\
$\begin{array}{c}\text { REACT oriented } \\
\text { learning }\end{array}$ & 92.7 & Very Good \\
Use of Language & 93.3 & Very Good \\
\hline Average & 91.8 & Very Good \\
\hline
\end{tabular}

The attractiveness of e-worksheet gets a percentage of $89.4 \%$ with very good criteria. In the REACT-oriented learning aspect, the percentage is $92.7 \%$ with very good criteria. in the aspect of language use, it got $93.3 \%$ with very good criteria. so that the overall average aspect of student responses to REACT-based e-worksheet is $91.8 \%$ with very good criteria. These results indicate that students agree that the REACT-based e-worksheet developed is attractive, by learning with the REACT strategy and easy-to-understand language.

Based on the results of student responses at the implementation stage, supporting data was also generated in the form of the achievement of learning skills stimulus using REACT-based e-worksheet which was seen from the REACT-based learning aspect. Table 10 shows the results of REACT's achievement at the Relating stage based on student responses.

Table 10. Student Response Questionnaire Data for Relating Statement Items

\begin{tabular}{ccc}
\hline Rated Aspect & Presentation (\%) & Criteria \\
\hline Relating & 90 & $\begin{array}{c}\text { Very } \\
\text { Good }\end{array}$ \\
\hline
\end{tabular}


Development Electronic Student Worksheet based on Relating, Experiencing, Applying, Cooperating, and Transferring (REACT) in Introduction to Chemistry and Laboratory

The achievement of the student's $4 \mathrm{C}$ skill stimulus using the REACT-based e-worksheet can be seen from the student's answers and student response questionnaires on the aspects of the REACT statement given. At the relating stage, which stimulates critical thinking skills in the form of assessing claims and arguments, it can be seen from the results of students' claims and arguments as well as from the results of student response questionnaires. Based on the results of claims on topic 1, on average, students can claim statements with the right answers, then on topic 2 students can give arguments to the questions given with good arguments. This shows that critical thinking assessment can be assessed through multiple-choice questions, for example, questions that require students to find the best conclusions on a certain set of data (Abidin, 2016).

Critical thinking can also be assessed with essay questions that require answers in the form of responses that contain a set of new and original ideas or at least in the form of expressing ideas in new ways. On the results of the student responses, the relating stage got a percentage of $90 \%$ with the "Very Good" criteria. Based on these results, it can be said that critical thinking skills have been stimulated well. Table 11 shows the results of the achievement stage of experiencing (Experiencing) based on student responses.

Table 11. Student Response Questionnaire Data Experiencing Statement Items

\begin{tabular}{ccc}
\hline Rated Aspect & Presentation (\%) & Criteria \\
\hline Experiencing & 88 & $\begin{array}{c}\text { Very } \\
\text { good }\end{array}$ \\
\hline
\end{tabular}

In the experiencing stage which is stimulating communication skills (Communication) in the form of the ability to read and understand various types of texts for various purposes and the ability to monitor the writing process, on topics I and II in the e-worksheet students carry out exploration and discovery activities in reading texts. Based on the results of the questionnaire, students' responses to the experiencing statement obtained a percentage of $88 \%$ with the "Very Good" criteria. Based on these results, it can be said that students' communication skills in terms of the ability to read and understand various types of texts for various purposes and the ability to monitor the writing process (Binkley et al., 2012) are well stimulated. This result is by Arifin (2014) that at the relating stage students are expected to be able to identify problems and provide simple explanations that encourage students to express their ideas, then these ideas can be used to build students' basic skills when students are in the experiencing stage. (Sapto et al., 2015). Table 12 shows the results of the achievement stage of applying (Applying) and based on student responses.

Table 12. Student Response Questionnaire Data for Applying

\begin{tabular}{ccc}
\hline Rated Aspect & Presentation (\%) & Criteria \\
\hline Applying & 92 & $\begin{array}{c}\text { Very } \\
\text { good }\end{array}$ \\
\hline
\end{tabular}

The applying stage serves to stimulate critical thinking skills in the form of explaining (stating results, justifying procedures, and presenting arguments). At this stage, students are given questions related to the reading text in the experiencing stage. Based on the answers given, students can explain the answers to the questions given well. The results of the percentage of student responses at the applying stage are $92 \%$ with the "Very Good" criteria. So it can be concluded that critical thinking skills at the applying stage are stimulated well. Table 13 shows the results of the achievement of the cooperative stage and student skills based on student responses at each stage.

Table 13. Student Response Questionnaire Data for Cooperating

\begin{tabular}{ccc}
\hline Rated Aspect & Percentation (\%) & Criteria \\
\hline Cooperating & 94 & $\begin{array}{c}\text { Very } \\
\text { good }\end{array}$ \\
\hline
\end{tabular}

The cooperating stage serves to stimulate collaboration and creativity skills. This stage should include students' communication skills to convey the ideas of each person in the group to achieve common goals (Abidin, 2016). The skills emphasized in this stage, are

This is an open access article under CC-BY-SA license (https://creativecommons.org/licenses/by-sa/4.0/) 
Development Electronic Student Worksheet based on Relating, Experiencing, Applying, Cooperating, and Transferring (REACT) in Introduction to Chemistry and Laboratory

collaboration skills when prioritizing, planning, and managing work to achieve group results and creativity and innovation skills in the form of creating new and valuable ideas (either additional or new concepts), developing creativity in the form of innovative ideas to in an impactful and adoptable form. In topic 1, students work together to make poster products, sorting chemical products based on their function in life. While on topic 2 students work together to plan the manufacture of simple disinfectant products by making trial journals or interim reports.

The results of the student response questionnaire at the collaboration stage got the highest percentage of $94 \%$, based on these results collaboration skills and student creativity were stimulated well. This is in line with Arifin (2014) that when discussing, students can provide further explanations and arrange strategies and tactics in applying the concepts they have learned in the applying stage. (Sapto et al., 2015). Table 14 shows the results of the transfer stage achievement based on student responses.

Table 14. Student Response Questionnaire Data for Transferring Statement Items

\begin{tabular}{lcc}
\hline Rated Aspect & Percentation (\%) & Criteria \\
\hline Transferring & 90 & $\begin{array}{c}\text { Very } \\
\text { good }\end{array}$ \\
\hline
\end{tabular}

The last stage is transferring stimulates critical thinking skills related to opinions or arguments, based on (Binkley et al., 2012) critical thinking has an operational definition, one of which is interpreting information, and drawing conclusions based on the best analysis, categorizing, understanding, and clarifying information. On topics I and II students are given news related to chemistry in everyday life, then students argue based on their best analysis. Based on the results of the arguments, students on average have given arguments with good answers. The results of student responses indicate the percentage at the transferring stage is $90 \%$ with the criteria "Very Good" so that critical thinking skills at this stage are stimulated well. These results are in accordance with Arifin (2014), at the stage of transferring in writing students can compose arguments and make conclusions (Sapto et al., 2015)

Overall, the REACT-based e-worksheet developed obtained a percentage on the average REACT-based learning aspect of 90.6\% with the criteria of "Very Good". Based on the results of these responses, it can also be seen that the development of REACT-based e-worksheet on the topic of knowing chemistry and laboratories is included in very good criteria and is suitable for use in the learning process that can stimulate students' 4C skills which are Critical thinking, Communication, Collaboration, and Creativity.

\subsection{Evaluation Stage}

The evaluation stage is the final stage in the R\&D (Research and Development) research method with the ADDIE model. The evaluation process is carried out by analyzing improvements to errors and deficiencies during the research process. This evaluation stage can also be carried out at every stage for improvement and follow-up of the correction results obtained from the input of various processes and suggestions from the validator. In accordance with the Tegeh Development research (2013) that in development research a formative evaluation is carried out to improve the resulting development product (Tegeh \& Kirna, 2013).

\section{Conclusion}

In this study, an e-worksheet based on Relating, Experiencing, Applying, Cooperating, and Transferring (REACT) was developed as a stimulant for students' 4C skills which was declared valid with the results of the content feasibility component being 0.82 , presentation at 0.79 , linguistic 0.82 , contextual of 0.80 , and graphic of 0.83 and at each stage stimulated one or more 4C skills, which are Critical thinking, Communication, Collaboration, and Creativity. Based on the results of student responses to REACT-based e-worksheet as a whole, the average aspect was $91.8 \%$ with the criteria of "Very Good". From the results of data processing, it can be said that the REACTbased e-worksheet is included in the "Very Good" criteria and is suitable for use in the 
Development Electronic Student Worksheet based on Relating, Experiencing, Applying, Cooperating, and Transferring (REACT) in Introduction to Chemistry and Laboratory

learning process. Suggestions for further researchers are the widespread implementation of e-worksheet, as well as the development of e-worksheet with various innovations that need to be carried out in accordance with the times.

\section{References}

Abidin, Y. (2016). Revitalisasi Penilaian Pembelajaran dalam Konteks Pendidikan Multiliterasi Abad Ke-21. Refika Adiatama.

Aiken, L. R. (1985). Three coefficients for analyzing the reliability and validity of ratings. Educational and Psychological Measurement, 45(1), 131-142. https://doi.org/10.1177/0013164485451 012

Binkley, M., Erstad, O., Herman, J., Raizen, S., Ripley, M., Miller-ricci, M., \& Rumble, M. (2012). Defi ning Twenty-First Century Skills. https://doi.org/10.1007/978-94007-2324-5

Corbeil, J. R., Dick, W., Carey, L., \& Carey, J. O. (2005). EDTC 6321: Instructional Design SUMMER I SYLLABUS. http://www.adobe.com/products/acrobat /readstep2.html

Dewi, T. A. P., \& Sadjiarto, A. (2021). Pelaksanaan Pembelajaran Daring Pada Masa Pandemi Covid-19. Jurnal Basicedu, 5(4), 1909-1917. https://doi.org/10.31004/basicedu.v5i4.1 094

Gu"nter. (2018). Research and Practice The effect of the REACT strategy on students ' achievements with regard to solubility equilibrium: using chemistry in contexts. https://doi.org/10.1039/c8rp00087e

Herdiana, D. (2020). Inovasi Proses Pembelajaran Daring bagi Mahasiswa Kelas Karyawan di Masa Pandemi Covid19. Konferensi Nasional Pendidikan I, June, 129-137. Retrieved from https://urbangreen.co.id/proceeding/ind ex.php/library/article/view/24

Herliandry, L. D., Nurhasanah, N., Suban, M. E., \& Kuswanto, H. (2020). Pembelajaran Pada Masa Pandemi Covid-19. JTP Jurnal Teknologi Pendidikan, 22(1), 6570.

https://doi.org/10.21009/jtp.v22i1.15286

Jamaluddin, D., Ratnasih, T., Gunawan, H., \& Paujiah, E. (2020). Pembelajaran Daring Masa Pandemik Covid-19 Pada Calon Guru: Hambatan, Solusi dan Proyeksi. Karya Tulis IImiah UIN Sunan Gunung Djjati Bandung, 1-10. Retrieved from http://digilib.uinsgd.ac.id/30518/

Khasanah, D. R. A. U., Pramudibyanto, H., \& Widuroyekti, B. (2020). Pendidikan Dalam Masa Pandemi Covid-19. Jurnal Sinestesia, 10(1), 41-48. Retrieved from https://sinestesia.pustaka.my.id/journal/ article/view/44

Makhrus, M., Harjono, A., Syukur, A., Bahri, S., \& Muntari. (2018). Identifikasi kesiapan LKPD guru terhadap keterampilan abad 21 pada pembelajaran IPA SMP. Jurnal Ilmiah Profesi Pendidikan, 3(2), 124-128. Retrieved from https://www.neliti.com/publications/298 728/identifikasi-kesiapan-lkpd-guruterhadap-keterampilan-abad-21-padapembelajaran

Nasrah, Jasruddin, \& Tawil, M. (2017). Pengembangan Perangkat Pembelajaran Fisika Berbasis Pendekatan Contexstual Teaching and Learning (CTL) untuk Memotivasi dan Meningkatkan Hasil Belajar Fisika Peserta Didik Kelas VIII SMP Negeri 1 Balocci Pangkep. Jurnal Pendidikan Fisika, 5(2), 235-248. https://doi.org/10.26618/jpf.v5i2.709

Nur, R., Darvina, Y., Syafriani, \& Satria, W. (2019). Validitas LKS Berbasis Problem Solving Untuk Mencapai Keterampilan 4C Pada Materi Suhu, Kalor, dan Teori Kinetik Gas Kelas XI SMA/MA. Pillar of Physics Education, $\quad 4, \quad 753-760$.

This is an open access article under CC-BY-SA license (https://creativecommons.org/licenses/by-sa/4.0/) 
Development Electronic Student Worksheet based on Relating, Experiencing, Applying, Cooperating, and Transferring (REACT) in Introduction to Chemistry and Laboratory

https://doi.org/10.22201/fq.18708404e.2 004.3.66178

Rahmawati, A., \& Yonata, B. (2019). The Development Of Student Worksheet Based In Contextual Teaching and Learning (CTL) To Practiced The Science Processes Skills. 8(2), 15-22. Retrieved from

https://core.ac.uk/download/pdf/230686 441.pdf

Redhana, I. W. (2019). Mengembangkan Keterampilan Abad Ke-21 dalam Pembelajaran Kimia. 1(Jurnal Inovasi Pendidikan Kimia), 2239-2253. https://doi.org/10.15294/jipk.v13i1.1782 4

Rezky, M. P., Sutarto, J., Prihatin, T., Yulianto, A., Haidar, I., \& Surel, A. (2019). Seminar Nasional Pascasarjana 2019. Generasi Milenial Yang Siap Menghadapi Era Revolusi Digital (Society 5.0 Dan Revolusi Industri 4.0) Di Bidang Pendidikan Melalui Pengembangan Sumber Daya Manusia, Universitas Negeri Semarang, 1118-1125. Retrieved from https://proceeding.unnes.ac.id/index.ph $\mathrm{p} / \mathrm{snpasca/article/view/424}$

Sapto, A. D., Suyitno, H., \& Susilo, B. E. (2015). Keefektifan Pembelajaran Strategi React Dengan Model Sscs Terhadap Kemampuan Komunikasi Matematika Dan Percaya Diri Siswa Kelas Viii. Unnes Journal of Mathematics Education., 4(3). https://doi.org/10.15294/ujme.v4i3.9049

Slamet Widodo, R. K. W. (2020). Mengajarkan Keterampilan Abad $21 \quad 4 C$ (Communication, Collaboration, Critical Thinking And Problem Solving, Creativity And Innovation) Di Sekolah Dasar. MODELING: Jurnal Program Studi PGMI, $7(2)$, 185-197. https://doi.org/10.36835/modeling.v7i2. 665

Subagia, I. W. (2014). Paradigma baru pembelajaran kimia sma.
Sugandi, A. I., \& Akbar, P. (2019). Efektivitas Penerapan Strategi React Terhadap Kemampuan Koneksi Matematis dan SelfEfficacy Siswa SMP. Jurnal Cendekia: Jurnal Pendidikan Matematika, 3(2), 431436.

https://doi.org/10.31004/cendekia.v3i2.1 17

Sugiyono. (2018). Metode Penelitian Kuantitatif, Kualitatif, dan R\&D. Alfabeta.

Tegeh, M., \& Kirna, M. (2013). Pengembangan Bahan Ajar Metode Penelitian Pendidikan dengan Model ADDIE. 2.

Winaryati, E. (2018). Penilaian Kompetensi Siswa Abad 21. Prosiding Seminar Nasional \& Internasional, 6(1), 6-19. Retrieved from https://jurnal.unimus.ac.id/index.php/ps n12012010/article/view/4070

Zidny, R., Sopandi, W., \& Kusrijadi, A. K. (2015). Gambaran Level Submikroskopik Untuk Menunjukkan Pemahaman Konsep Siswa Pada Materi Persamaan Kimia Dan Stoikiometri. Jurnal Penelitian Dan Pembelajaran IPA, 1(1), 42. https://doi.org/10.30870/jppi.v1i1.326 